Comparative Philosophy Volume 8, No. 1 (2017): 28-46

Open Access / ISSN 2151-6014

www.comparativephilosophy.org

\title{
BETWEEN THE INTERNAL AND THE EXTERNAL: KANT'S AND PATAÑJALI'S ARGUMENTS FOR THE REALITY OF PHYSICAL OBJECTS AND THEIR INDEPENDENCE FROM MIND
}

\author{
ANA LAURA FUNES MADEREY
}

\begin{abstract}
Although coming from two very different paths, both Kant and Patanjali present similar strategies to refute the skeptic argument that denies the real and independent existence of physical objects. This essay examines both strategies through the reconstruction of Kant's and Patañjali's twofold refutation of idealism: one based on the perceptual distinction between the real and the illusory, and the other one based on the ontological necessity of a permanent external object to understand change. I argue that the second strategy is philosophically stronger due to its phenomenological recognition of the body as a grounding point, and that this is possible only on account of an anti-realist conception of time. Both Kant and Patañjali utilize a similar line of realist argumentation while diverging in the type of realism that they each hold.
\end{abstract}

Keywords: change, external, internal, Kant, Patañjali, realism, refutation of idealism, time

\section{INTRODUCTION: THE ARGUMENT FROM ILLUSION}

It is common sense to trust in sense perception as a valid means to know the world and the environment. But it is also common to have sensory experiences that fool our mind. Experiences of perceptual illusions such as the bent straw on a glass of water, or a white wall that looks yellow under a yellow light, or the serpent that is confused with a rope, etc., have made philosophers, both Western and Eastern, doubt not only the idea that we have direct and true perception of ordinary external objects, but also that those objects exist apart from our perceptions.

Skepticism about perceived objects, in its most drastic form, stems out of the premise that there is no phenomenological difference between perceptual illusions, dreams, and what we usually take as genuine perception, since all perceptual appearances are experienced as pertaining to a real object or event. If this is the case with common illusory experiences, what could prevent us from thinking that all our

FUNES MADEREY, ANA LAURA: Clinical Assistant Professor of Yoga Studies, Loyola Marymount University, California, USA. Email: afunesma@lmu.edu 
perceptions are but illusions or mere dreams? There are many cases where the content of experience can present itself without an external object (supposing there is one), such as in dreams. If there is any case where the content of our sensory experience were caused by actual external objects, how would we know? For all we perceive is the content of our experience which presents itself as a cognition, however objective, subjective, or self-luminous it appears to be.

A typical attempt to refute the skeptic or illusion argument relies on the denial of the assumption that there is no phenomenological difference between illusion and reality by insisting to show that there is an intrinsic distinction between the internal and the external. The criterion is usually established based on a causal or perceptual difference. Dreams or illusory objects would be different from reality in that they are objects of perception caused by a particular state of mind (sleep or hallucination) which produces a set of sensations that do not point to anything beyond them. Real objects, in contrast, are caused by a direct contact with that which is perceived causing a set of sensations that refer, point, or signal something beyond them. Unfortunately, this way of responding to the skeptic argument begs the question, since the account of such difference is given in the same terms that need to be proved: the distinction between the real and apparent sense-object contact.

A more powerful way of arguing against the argument from illusion can be found in the strategy deployed by Kant's famous refutation of idealism in the Critique of Pure Reason (CPR) and in the argument against the Yogācāra Buddhist position elaborated in Patañjali's Yogasūtra (YS) and its main commentary, the Yogabhāṣya of Vyāsa $(Y B h) .{ }^{1}$ This strategy consists in proving that there cannot be experience of the internal without presupposing the experience of the external. In this essay I examine how both Kant and Patañjali, although coming from two very different paths (transcendental idealism, the first one and metaphysical dualism, the second one) offer a parallel line of argumentation to defend the reality of physical objects. I argue that this argumentative strategy is stronger than the one based only on a perceptual criterion due to its anti-realist conception of time and the phenomenological recognition of the body as a grounding point for the external.

Kant and Patañjali conceive time in a way that is not independent of our modes of cognizing it. Since all perceptions (whether real or illusory) appear in our mind ordered in time, both philosophers think that it would be impossible to make sense of such temporal determinations without an enduring object external to the mental variations present to the self. Moreover, they both argue that, without an external reality, no internal mental states could occur at all.

While there is a realistic line of argument running parallel in both Kant and Patañjali, they both diverge in the intrinsic characteristic of the externality of reality. The element by which the experience of the internal is dependent upon the existence

\footnotetext{
1 The Yogasūtra of Patañjali and Vyāsa's commentary have been recently considered as a unified whole that was possibly composed by the same author between 325 and 425 CE (See Mass 2013). Taken together: the sütra-s and the bhāsya are called Yogaśāstra. In this article, both Patañjali and Vyāsa (whether they are the same person or not) are taken as the representatives of the classical Yoga philosophy here discussed.
} 
of the external will be shown through the reconstruction of Kant's argument for the externality of a permanent object and Patañjali's argument for the externality of change. Interestingly, it is precisely their point of divergence that makes their very distinct metaphysical positions meet at the level of a transcendental argument. As it will be seen in the conclusion, Kant's transcendental idealism can only provide a strong proof against the skeptic argument from illusion if his refutation of idealism is interpreted at face value. At the same time, Patañjali's metaphysical realism only shows its strength against Buddhist idealism by deploying anti-realistic elements in its analysis of time. By attending to the types of realism that both Kant and Patañjali are advocating, a stronger strategy against the argument from illusion is shown here that avoids begging the question about the distinction between the internal and the external.

\section{KANT'S ARGUMENT FOR THE EXTERNALITY OF A PERMANENT OBJECT}

\subsection{TIME IS NOT REAL IN ITSELF BUT ALL OBJECTS APPEAR WITHIN TIME}

Kant conceded the main point to the argument from illusion: that we only have immediate perception of what appears in our consciousness. However, Kant made a further observation. What is presented in our consciousness as an experience can only appear in a spatiotemporal way $(C P R, \mathrm{~B} 60)$. Since time and space are the forms by which our intuition apprehends any object, they constitute a priori conditions of possibility for our experience of objects. There is simply no experience of objects, no sensations, to which we do not apply our subjective forms of intuition.

An ambiguous distinction between external and internal is created the moment that space and time are taken as the subjective forms by which we perceive things. Kant excludes the idea that time and space are external realities, empirical objects of experience. Instead, both forms of sensibility are internal in the sense that they determine how our intuition, one of our cognitive functions, works. These forms "attach" to our sensibility, regardless of the content of sensations ( $C P R, \mathrm{~A} 43)$. In doing so, they take us forever apart from the cognition of objects in themselves, that is, from knowing them independently of our spatiotemporal experience. This, however, does not make of Kant a skeptic because, since we do not and cannot know anything about the objects independent of our sensibility, we could not even claim that they are outside of us. It would be like applying a category to that which by definition cannot be determined. An absolute distinction between internal and external is merely conceptual, and it should not be taken as referring to the view that says that appearances are partial and defective perceptions of the real thing, for such distinction (between appearance or perceptual illusion and reality) is and can only be an empirical one (CPR, A45).

It is precisely within the empirical realm that we can legitimately make the distinction between inner and outer, for those distinctions are intrinsic to and 
dependent on our forms of sensibility. An external object, then, is a presentation that appears to our consciousness as outside of ourselves by means of the outer sense of which form is space. An internal object, by contrast, appears to our consciousness by means of the inner sense, which makes the mind intuit its inner states as objects that appear already ordered in temporal succession (CPR, A23). Since both internal and external objects are nothing but presentations, we have immediate awareness of them. Therefore, it is on the "direct testimony" of our own self-consciousness that we can say that external things exist just as much as our own existence as subjects. According to the first attempt by Kant to refute idealism in the Fourth Paralogism of the Critique, it is this direct perception of the inner objects as one's thoughts and the outer objects as in space which gives "a sufficient proof of their actuality" $(C P R$, A371).

However, as it was mentioned in the introduction, a distinction appealing to perception is not enough to refute the argument from illusion because it begs the question regarding the criterion itself. Nevertheless, these preliminary steps paved the path for the stronger proof Kant provided to refute idealism. Once the immediate knowledge of all our presentations has been conceded by means of their appearance through the inner sense, the form of which is time, Kant then puts into question the sufficiency of this premise, assumed by the argument from illusion, to explain the experience of spatial objects as external.

\subsection{TEMPORAL VARIATIONS ONLY MAKE SENSE IF THERE IS A PERMANENT OBJECT}

All objects of experience appear determined in time indistinctively of their reality or non-reality. But if all objects of experience are subject to temporal variation, then how can the experience of a permanent object be explained? If today I see that the only banana in the fruit basket is somewhat green and three days later I see it yellow, the only way I can make sense of both successive presentations is by presupposing that there is one object to which both mutations apply. Otherwise I would not think it is the same banana which has undergone change.

According to Kant, change implies the permanence of an object. The multiplicity of sense data, i.e. manifold of appearances, is apprehended through the temporal form of intuition which makes it always appear in succession. But the apprehension of the manifold by itself is not yet a unity, or object of experience. It can only become a unity when it has been determined by the categories of the understanding. The variations of time determinations can only be understood through the category of substance, i.e., through the concept applied to the intuition of an enduring object distinct to the time determinations themselves ( $C P R, \mathrm{~B} 225)$. Such an intuition is only possible by means of the outer sense, for it is due to the form of space that we can locate an object in its temporal relations, not only as sequential but also as simultaneous to something else. Otherwise, our consciousness would be presented merely with a succession of appearances, which would be felt as an always vanishing and starting existence, but never experienced as an object. 
For a Buddhist idealist like the one we will find Patañjali discussing against, this "counterintuitive" conclusion is precisely the natural consequence of a right understanding of change. Indeed, one could object that Kant's argument relies on the assumption that change can only be predicated on permanence, but couldn't the Buddhist idealist say that this is as erroneous as our belief in an external world? With proper understanding and view on how things appear in our mind, we would eventually be able to experience things as they really are, that is, as nothing but fleeting, impermanent presentations.

Yet, in defense of Kant, we could say that he admits this experience as common: that all we find in our minds through the inner sense are fleeting temporal presentations. And yet, it is also true that we do have the experience of permanent objects. The problem is how to explain that, given those temporal and fleeting presentations, the experience of a permanent object is possible. To respond that the experience of a permanent object is product of an erroneous understanding would be, for Kant, to apply illegitimately our categories of intuition, because the very distinction between "permanent" and "changing" is an empirical one. To say that everything is "in reality" constantly changing would be to admit that there are temporal determinations independent of our experience, and that contradicts the very position that denies something being external to consciousness. The experience of a permanent object is not only possible but empirically necessary. Without the appearance of a permanent object in perception, the manifold received through our sensibility would not make any sense experientially. But of course, the appearance of a permanent object does not imply that it is external to the mind. This is what the next part of the argument will establish.

\subsection{THE PERMANENT OBJECT IS NECESSARILY OUTSIDE ONESELF}

That all determination in time presupposes something permanent in perception is the second premise of Kant's famous argument for the refutation of idealism in the second edition of the Critique of Pure Reason (CPR, B274-279). In this argument, Kant sets out to prove that the experience of a permanent substance must refer to something outside of one's own consciousness. It is not possible to prove this by appealing to the temporal determinations of an object in reference to something permanent because, as previously discussed, both permanence and variation could still be dependent upon the mind. But what would be the outcome if we considered the temporal determinations of a subject? As the first premise of this argument states: "I am conscious of my own existence as determined in time". If one is to make any sense of the temporal determinations referring to one's own existence then one must presuppose something permanent in perception. But, the argument continues, this permanent cannot be something within me. If the permanent were within me, it would be a presentation itself subjected to time and, therefore, in need of something permanent distinct from itself by reference to which it is a variation, i.e., a temporal determination. Thus, the permanent by which I determine my existence in time must be outside me. 
Something in this argument does not seem to work. Why could I not consider something within myself as the permanent substance in relation to which my own temporal determinations could be understood? If we followed Kant's own argument about the necessity of a substance, then we would have to conclude that there is a permanent substance within myself, otherwise, where would the changing mental states occur? ${ }^{2}$ How would I make sense of the constant variations that occur within myself in reference to an external object and not in reference to me? Why does the permanent substance have to be presented necessarily as an object in perception rather than as a perceiving subject?

One reason is that, for Kant, the self is not and cannot be an object of perception; instead, it is the pure act or the pure condition of perceiving. The transcendental subject of apperception is fundamental for the possibility of all the synthesis needed in the process of knowing an object. When Kant talks about the temporal determinations of the self he is referring to the "I" of which we are aware as the empirical self, that self which is constituted by all the inner temporal states of the mind. The empirical self is the historical self, the one that is, for example, an irreverent atheist at one period of her time and a converted devotee theist at a later time; the one that yesterday was happy but today is sad, etc. There is here, indeed, an implied distinction between, at least, two levels of the self. By proving that the permanent substance has to be necessarily outside the empirical self in order for this one to be temporally determined, Kant is also arguing for the impossibility of considering the transcendental self as permanent, although not precisely for Humean reasons, but because of a deeper realization regarding our inner sense. This can be clearly seen in the following reconstruction of Kant's argument.

Intuitions that are perceived directly through the inner sense are always given as a manifold of mental states, a "flow of inner appearances" (CPR, A107). Since the formal condition of inner sense is time, those mental states appear always in a temporal succession. The inner sense or empirical apperception can never intuit the mind as something permanent or enduring. But just as we are not able to relate temporal determinations to an external object unless we are given in perception a permanent object on which they occur, it would not be possible to relate such determinations to ourselves if there were no synthetic process that presented them determining our own mind as an individual (CPR, Q107-109). So how can the mind be conscious of those temporal inner variations as determining my self?

In the Trascendental Logic section of the Critique (A108) Kant says that the mind would not be able to "think its own identity in the manifoldness of its presentations" if it did not have present to it the identity of its act, that is, the identity of its knowing objects through the synthetic processes that make them appear to it as a unity in relation and coherence to other presentations. Suppose there is the current inner state of perceiving a photograph, followed by the presentation of some memories, and then the emotion of nostalgia, and then perhaps also the desire to come together with the person in the photo again. Those cognitions already presuppose a synthetic process

\footnotetext{
${ }^{2}$ See Arindam Chakrabarti's treatment of this point in $(1992,102-3)$.
} 
that presents them, through the categories of the understanding, as objects of experience (some external, some internal). They would be nothing for me, or would not even appear to me, unless they were referred to the act of me-thinking-them, i.e. the I think.

This self-consciousness or original apperception, as Kant calls it, is not perceived, but spontaneously thought in each and every presentation that appears before our own mind. The self of whom I am conscious as determined in time cannot be the transcendental self, for this one is always identified as the same in each and every present moment. Because it is unchanging, it is not subject to time. That which is not conditioned by time cannot be determined as permanent, for this concept is only understood in relation to duration within time. Therefore, the transcendental self cannot be the permanent within us not because we cannot perceive anything permanent in us, but because even if we could perceive it through an intellectual intuition, it would not be something permanent, for the concept of permanence cannot be applied to it at all. Kant does not really put it in this way, but it seems to be the best way to explain why the permanent could not be within us following his own line of argumentation.

\subsection{WITHOUT AN EXTERNAL OBJECT, NO INTERNAL APPEARANCE IS POSSIBLE}

That the transcendental self cannot be the permanent substance that makes sense of one's temporal determinations according to Kant has been sufficiently established, but it is still not clear how a permanent object outside oneself is needed to make possible the temporal determinations regarding the empirical self. One plausible way of understanding this premise is the one suggested by Paul Guyer (1987, 306). According to him what Kant means is that one can only know the occurrence of inner representations as successive in one's own experience through their being simultaneous with successive states respective to some enduring thing. Just as we only understand the temporal variations in external objects by reference to a permanent object in space (the example given by Kant is that of the temporal variations on earth with respect to the sun), we can only understand how one mental state - say, my perception of the sunset and feeling of happiness-has succeeded another-for example my perception of the sun overhead and feeling of being uncomfortable-because one state was simultaneous with a perceived external object - the sun over the horizon and my feeling of happiness vs. the sun at the zenith and my feeling uncomfortable. One knows that some inner states are in the past and others are now in the present because one realizes that one's own past states were simultaneous with a past state of an external enduring object (for example, the sun) which is now on a different state simultaneous with one's own present inner states (Vogel 1993, 885). Thus, it is only the perception of an enduring object outside

oneself which can provide the temporal relation of simultaneity and through this the understanding of my inner states as successive. 
This interpretation explains the way in which a permanent something outside oneself makes possible the temporal relation of simultaneity, but it does not explain how it is that I can know myself as having those inner states just by being able to relate the successive inner states with their respective successive states on an external enduring thing. The problem in this explanation for the purpose of refuting the argument from illusion is that we could still conceive the possibility of those perceptions, however spatial and simultaneous, as being virtual projections in which we are taking part as characters of a computer game (Hanna 2000, 164).

Kant's argument about the reality of physical objects turns out to be stronger if the element by which it is possible to determine oneself temporally is made to depend not to so much on the permanence of an object, but on the fact that such an object is outside one's own conscious states. Although this might sound again as begging the question, this interpretation, suggested by Cassam $(1993,11)$ and Hanna $(2000,170)$, points to the transcendental move that Kant is actually making, at the same time that it recovers Guyer's interpretation of the external objects in Kant at face value, that is, as objects and not as representations.

According to Kant, for an object to be outside myself, the only thing it needs to satisfy is the condition of being spatial. But such condition is perfectly fulfilled by one's own body. It seems as if Kant and classical interpretations of his argument had overlooked the possibility of relating the empirical self to the external object as something proximal rather than only distal. However, if empirical self-consciousness requires the perception of outer objects for its temporal determination, there is nothing else except the body which can provide that. Kant himself defined the outer sense in his Anthropology (Book I, 15, 153) as the sense "where the human body is affected by physical things". The body is affected by physical things in virtue of its "original passivity" (Förster 1985, 307). And such original passivity is constituted by the receptivity of the five senses, which is defined as "the condition of sensibility under which alone outer intuition is possible for us" (Kant CPR, A26/B42).

Thus, we could reinterpret Kant's premise as saying the following: we would not be able to know ourselves as temporal beings without the existence of our own body, not only because the body functions as the permanent object by means of which temporal mental states can be apprehended as belonging to oneself; but also because without the body, our mind would not have any material out of which to apprehend anything through its inner sense. In this way, our body, i.e. the locus of the outer sense, is the condition of possibility for inner experience. From this it follows that there is simply nothing that can be produced in the mind by the mind itself. Whatever is presented in the mind has been previously given. And the condition of possibility for something to be given to our minds is an original and authentic receptivity, an element that is necessarily found in a physical object such as one's own body. Thus, without the existence of one's own body and the rest of physical objects with which it interacts, determination (real or illusory) of one's own existence in time would be impossible. It is in this sense that determination of my existence in time proves the existence of actual things outside me. 
Reconstructing Kant's argument in this way presents a strong objection to the argument from illusion because it does not appeal to a difference in perception between imagination and reality, change and permanence. Instead, what it says is that imaginations, illusions, dreams or hallucinations would not occur in the first place were there not originally a given intuition that provided the content for them. The argument from illusion presupposes that hallucinatory, illusion, or dream experiences do not have objects which are external to the mind and, since there is no phenomenological difference between these and "real" experiences, it concludes that there are no external objects. This conclusion implies that consciousness can give itself a content. But it is impossible to make sense of an act of spontaneity without something upon which it can act. Even a skeptic absolute idealist like the one subscribing to the argument from illusion would have to accept consciousness as a pure act of spontaneity. But making pure consciousness act upon itself would introduce an element of passivity that would have to be accounted for by something that is not spontaneous (and therefore external to its nature). This, however, would be contradictory to the very concept of consciousness implied in the argument from illusion, as will also be seen in a similar realistic line of argumentation such as the one found in Patañjali.

\section{PATAÑJALI'S ARGUMENT FOR THE EXTERNALITY OF CHANGE}

\subsection{THE OBJECTIVE WORLD IS BOTH EXTERNAL AND INTERNAL}

The strength of a realist argument against the view that holds objects to be a product of cognition only and thus, without real existence, depends on a transcendental move that provides not so much criteria to distinguish between external and internal objects, but a relation of ontological necessity of the internal determinations upon an external object. This strategy is also found in Patañjali's argument against the position held by Yogācāra Buddhism.

Patañjali shares with Kant the characterization of the inner mental states as sequential, ephemeral and ever fluctuating, but departs from the German philosopher in that a clear distinction is made, at the outset, between the fluctuating mental functions (cittavrtti) and the immutable self that is conscious of them (YS, I.2-4). Perceptions, correct and incorrect cognitions, imaginations, dreams and memories are the mental representations brought to consciousness through the faculties of the mind: attention (manas), self-identification (asmitā), and intellect or understanding (buddhi). The mind is considered to be internal with respect to the physical body and the physical objects. But a further distinction is also made between the state of the mind when it is focused on an object (be it internal or external) and the arrested state of the mind when it is object-less or "without seed" (nirbija-samädhi); the former being an external function with respect to the latter (YS, III.7-8). ${ }^{3}$

\footnotetext{
3 Vyāsa (YBh, I.1) also calls it asamprajñāta-samādhi, the mental state where all the fluctuations of the mind are stopped.
} 
A mental state without an object or no representations at all would render the mind unconscious and without the intentionality that characterizes subjectivity. If this state were possible and, at the same time, we were aware of it, then it would mean that consciousness is different, not only from any mental representation, but from the mind as well. This is precisely what is claimed in the Yogasūtra of Patañjali. An object-less state of awareness is possible. Therefore, if consciousness is different from the mind, then both physical objects and the mind itself fall into the same category: that of being an object of consciousness. Both physical and mental objects together with the mental cognitive faculties constitute the objective world (vastutattvam). ${ }^{4}$

The question about the criterion for the distinction between what is inside and outside the mind appears now with double force because even if it is true that the objective world encompasses not only physical, but also mental objects, the question is whether that "objective world" is independent of consciousness. Vyāsa (YSbh IV.16), just as the Yogācāra idealist, accepts the premise that consciousness is the true subject. The idealist question still hunts us. If this is true, then how could we know that the world is not a manifestation created by consciousness alone? The whole existence of the so called "objective world" could be dependent and simultaneous to its perception by consciousness, just as objects such as pleasure, pain, etc. exist as long as they are perceived and experienced by a mind.

\subsection{THE EXTERNAL OBJECT CANNOT DEPEND FOR ITS EXISTENCE ON ONE MIND}

Patañjali claims in sūtra IV.16 that an external object does not depend for its existence on one mind. If it did, what would happen to the object when it is not being perceived? Vyāsa expands the argument in his commentary to this verse. If an object were dependent on one mind and it stopped being perceived by that mind or any other mind then, following the idealist thesis, the object would stop existing. But if it comes back into contact with the same mind again and it is admitted to be the same object that was perceived before, then the idealist view would have to admit that an object can come to existence out of nothing, which is absurd. However, the idealist response (specially of the Buddhist type) could accept that it is not the same object that appears, nor the same mind that observes it; the experience of continuity being itself a construction made by consciousness based on the similarity between objects.

Still, another implication of this idealist view according to Vyāsa would be that an unknown or unperceived part of an object that is being cognized would be nonexistent. This would mean, for example, that someone's back-supposing she is against the wall and nobody is observing her from behind - would not exist because it is not being perceived by anyone. If this is true, then the belly (or any front part of the perceived body that depends on the back to exist) could not be known either

\footnotetext{
${ }^{4}$ See YS IV.14 and II.18 where the objective world is called dr'syam, "the seen" and consciousness is drștr or purușa, "the seer".
} 
(since one of its constitutive parts would be missing). If the belly is not known, then it is non-existent. But this is absurd since the belly is being actually perceived ( $Y B h$, IV.16).

Vyāsa's argument relies on the idea that without considering the object as permanent, the idealist position falls into contradictions. The Yogasütra of Patañjali shares with Kant the view that without conceiving the object as permanent, i.e. as the same from one moment to another, we would not be able to understand change. Patañjali adds to this that we would also not be able to make sense of the difference in the ideas that the same object causes in different minds. For example, we would not be able to understand how someone feels love for her mother, while her sister hates her. If the object of perception did not remain, then we would have to say that they are referring to a different mother each, but that would be absurd.

If the object is created by the mind, then which mind would be the creator of this common object? If the common object were a creation of the mind, it would have to cause the same idea in all the minds, but this is very unlikely to happen under normal circumstances. Usually different minds react in a different way with respect to a common object, without the risk of confusion. On the account of such a divergence between the minds and the same object, Patañjali and Vyāsa's commentary claim that internal objects of the mind and external physical objects are ontologically different ( $Y S$ and $Y B h$, IV.15). The perception of an object, according to classical yoga philosophy, is a direct coming-into-contact between the mind and the object whose configuration (gunas) causes a change in the mind which can react differently according to the individual.

At this point, all Patañjali and Vyāsa have established with these arguments is the distinction between the external objects and the personal minds within the objective world (vastutattvam). But it is not clear yet that the independence of the objective world with regard to consciousness has been proved. Such distinction could still be just a creation of the transcendental consciousness or a manifestation within it. Patañjali and Vyāsa need a stronger argument to refute this. As will be shown next, this strength will be achieved with a transcendental move made possible by the peculiar anti-realist notion of time present in the Yogasūtra.

\subsection{CHANGE (PARINÃMA) IS REAL, TEMPORAL DETERMINATIONS ARE NOT}

For Patañjali as for Kant, determinations in time cannot be understood without the notion of a permanent substance. But what exactly are these determinations in time for Patañjali? Three basic modes of change or transformation (parin̄āma) regarding both external and internal objects are described in the Yogasütra (YS and YBh III.13). First, there is change in characteristics (dharma); second, there is change in temporal state (laksana); and third, there is change in condition (avasthā).

Each mode of change (parināma) is in relation to that which changes in the previous mode. Only the characteristics pertaining to a substance change in temporal state and only the temporal states of the characteristics make the substance undergo a 
change in condition. Consider a gold vessel as an example. When molten, the gold substance undergoes change in characteristics (dharma), going from its vessel shape into a bracelet. The substance "gold" does not change. It is only the characteristics that change into past, present, and future. The characteristic of being a bracelet is now in the present, while that of being a vessel is in the past, and the one of being possibly a coin (or something else) is in the future. But the golden vessel also undergoes change every moment even if there is no other evident characteristic manifesting upon it. Every moment the golden vessel is becoming older. The change in condition (avastha) is in relation to the characteristics in time which, even while appearing stable in the present, they are changing from being new to becoming old.

While present, past, and future are temporal states (lakṣaṇa), Patañjali and Vyāsa consider them to exist simultaneously all the time only in the sense that, while the present moment exhibits a particular characteristic of the substance, both past and future characteristics remain unmanifested (avyakta), one as a quiescent trace of what once was perceivable, and the other, as a latent potentiality to emerge (YS III.14). Past and future do not exist as separate simultaneous moments, contiguous to the present, nor do they vanish into non-existence the moment they cease to be perceived. If they became non-existent, Vyāsa argues, there could not be knowledge of the past or knowledge of the possible future, nor reappearance of a past characteristic in a substance. Knowledge of past characteristics is possible, since they are the causes of the manifested present mode. We can know of the present golden vessel that it was a piece of gold before, and that it could be a bracelet in the future. Or we can know that a past mental state, like anger, could come back in a later time given certain conditions. Without both past and future existing in the present moment as unmanifested configurations, the present and future characteristics of a substance would not be able to exist, for existence cannot come out of non-existence.

This account of time does not seem very anti-realistic, but on the contrary. To say that past and future exist even without being perceived is precisely to state that time exists independently of our cognition. Vyāsa even goes on to say that, while all temporal states exist in the present, this does not mean that all characteristics of the substance manifest at the same time. Someone could be in a manifested happy mental state because of a job promotion, while also holding an unmanifested inner grief for the recent death of a loved one, making her burst into tears at a later time. Yet, Vyāsa's or Patañjali's anti-realism of time consists in denying that past and future exist objectively, that is, independently of their being manifested or unmanifested to the experience. If past or future had an objective, that is, "real" existence in their own terms, then all characteristics would manifest simultaneously in the same object. But this is not the case. All we have experience of is the present moment (kșana), where only a certain characteristic or a certain set of characteristics are manifest while others remain in their latent form. ${ }^{5}$

${ }^{5}$ See Anindita Niyogi Baslslev (1983) for an in depth analysis of the non-objectivity of time determinations in the Yogasūtra of Patañjali. 
No two moments can co-exist together, which means that what we consider to be a sequence of moments such as a week, day or an hour, are all just mental constructions. The determinations of "later-than" and "earlier-than" occur only within the concept of a sequence, but have no objective reality. To talk in terms of a past moment and a future moment is misleading, for these are only labels, "qualifying adjuncts" to account for the conventional time. The reality is, Vyāsa explains, that in one present moment the whole universe is experiencing a change ( $Y B h$ III.52). A change or mutation is the coming to a manifested state of a future characteristic on the disappearance of a past one in a substance which remains the same ( $Y B h$ III.13).

\subsection{WITHOUT THE EXTERNALITY OF CHANGE, NO CONSCIOUS STATE IS POSSIBLE}

It can be seen, then, that Patañjali makes the notion of time dependent on the existence of a mutation, and a mutation is the undergoing of the three modes of change at once. According to the Yogasutra, there could be no temporal experience if there were no real change in the objective world. At the same time, change in the objective world is perceived as a sequence (krama) and succession by our normal consciousness, just as it is attested by the immediate experience of our own fleeting mental states. But even though the succession and collection of moments is a mental construction, we would not be able to construct it if there were no real moment on which to base it on.

A deeper view into the mode of change in characteristics (dharma) reveals that what remains as a substance through a certain period of time is itself a characteristic of another one. The vessel and the bracelets are characteristics of gold, but gold is a variation of mineral matter, and this could manifest as silver, copper, etc. If we mentally followed the process of finding the unmanifested characteristics out of which the present ones have emerged, we would realize that there is no immutable permanent substance even though, empirically, we do not grasp the temporal variations without an object that endures through them. A "phenomenological regress" is the method proposed by the Yogasütra to get to the understanding of the original conditions of experience.

All objects of the world (external or internal) undergo the three modes of change. Since access to the external world is mediated by our own body, the Yogasutra proposes a phenomenological regress that starts out from the observation of the manifested characteristics of that which is the condition of possibility to experience them. Thus, it can be seen that the different activities performed by our body for its own survival through its limbs and organs ${ }^{6}$ are modifications of bodily activities. The physical body is a variation of physical bodies in general. Bodies are variations of the physical elements. Elements are variations in the combination of atoms. Atoms are

\footnotetext{
6 The organs by which we perform actions that are vital are called karmendriyas and the yoga philosophy classifies them in five groups: the vocal, manual, locomotive, excremental and procreative, as enumerated by Vyāsa in his commentary to II.19.
} 
the objective characteristic of more minute particles. Particles are the objective elements of the individuating principle of matter. Considered from the subjective point of view, the five senses are variations of the mode of perception. Perceptions are a variation of the contents of our mind (cognitions, imaginations, etc). Our mind is the subjective variation of the individuating principle of matter. The individuating principle (asmitāmātra) is a variation of the pure principle of determination (mahat). ${ }^{7}$

As such, the pure principle of determination underlies every differentiation and corresponds to the innermost state of an arrested and object-less mind. A mind that is free from mental modifications presents itself as if there were no mutation happening. However, that stage manifests precisely because a mutation is going on. This "original mutation", however, is not given to experience, for it is the very condition of possibility for manifestation and for any further change. A transcendentalphenomenological analysis of change reveals, as Anindita Niyogi $(1983,109)$ says, a deep insight: that which changes cannot take note of itself as change, for the same reason that a variation in time cannot be understood as such unless it is related to something fixed and external to it. Therefore, if there is something mutable in itself, it cannot be conscious. That which, on the other hand, is conscious of change, is itself devoid of all mutation. Change can only become conscious of itself in relation to that which does not change; and this is what constitutes the original mutation, the possibility of temporal experience.

The argument from illusion suggests that consciousness can be transformed in and by itself, but according to the analysis of temporal experience, as Patañjali and Vyāsa understand it, this proves to be impossible. If consciousness underwent change in and by itself, there would be no way by which it could be conscious of its own mutations and recognize them as its own without a fixed point external to them. Consciousness would be just an unconscious series of mutations, and that is absurd.

Thus, the real, external existence of the objective world is required for consciousness to experience itself, just as much as consciousness is needed in order for the original mutation to take place. The conscious and unconscious principles are external to each other, although timelessly related. If, as Sinha suggests (1983, 52), there is a possibility for "timeless change" according to the Yogasütra of Patañjali, it would be the original moment of mutation when consciousness relates itself, through a cognitive process, to that which it is not. How else could consciousness relate to something if it was not through its own ability of "cognizing"?

This argument for the reality and necessity of an external world could work as a stronger strategy in the Yogasütra of Patañjali to refute idealism and the argument

\footnotetext{
${ }^{7}$ Vyāsa and the Yogasūtra follow the Sämkhya school in the description of the manifestation process of the objective world, which is called prakrti in that system. I am using the term "pure principle of determination" for mahat, because it is called lingamātra in the Yogasütra, which literally means "indicator-only" and refers to the first manifested element in the process of transformation of matter or prakrti. According to yoga philosophy, mahat has the characteristic of intellect, that is, it has the ability to grasp the universal ideas that will then manifest in particulars through a process of individuation. It is the ability to "grasp" and then emit a judgement on reality what is being called here "the pure principle of determination".
} 
from illusion without begging the question, for it then poses the burden on the other side to explain how it is possible that the principle of consciousness could undergo change without contradicting itself.

\section{CONCLUSION}

Both Kant and Patañjali together with Vyāsa's commentary provide elaborate arguments to prove the reality of an objective world independent of the mind. The arguments that rely on a perceptual criterion are not fully successful because describing the difference between the internal and the external in order to say that there is a direct perception of such distinction does not explain away the possibility that such distinction be caused within the same mechanisms of the mind or the consciousness.

We then analyzed the possibility of arguing against idealism and the argument from illusion with a different strategy that did not rely on a perceptual criterion. Such a move could be found both in Kant's argument for the refutation of idealism and the reconstruction of an argument against Buddhist idealism from the Yogasutra of Patañjali and Vyāsa's commentary. It was shown that the second strategy consisted in making the internal experience ontologically dependent upon the existence of the external. We saw that this was possible mainly by 1) conceiving time in an anti-realist way, that is, not independent of our modes of cognizing it, and 2) finding that element by which the experience of the internal is dependent upon the existence of the external - the passivity and original receptivity of the body in Kant, and the original mutation of the unconscious principle in the Yogasütra.

The basic steps for a stronger argument against idealism in general would be first, to prove the mind-dependency of time. By doing this, an important premise of the argument from illusion is conceded: that all objects of experience (whether spatial or not) appear indistinctively directly to the mind given that all of them are determined by time, which is itself a way in which the mind organizes its variations. The realist argument then sets out to show that, if we accept this premise, concluding the mind-dependency of all objects of experience would lead to a contradiction. Second, it is then necessary to show that, without a fixed point different to the internal variations, time determinations cannot be understood at all in a way that makes sense to our experience. Third, the transcendental move is required to prove that without an enduring external real object, no internal mental states can occur at all. Finally, the argument should exhibit the internal contradiction of suggesting that the objective world is metaphysically dependent on the mind.

While Kant and Patañjali's realist line of argumentation include all these elements, we find them both advocating very different types of realism. Kant describes his position in the Fourth Paralogism (CPR, A370) of the Critique as a "transcendental idealism" while being at the same time "empirically realist". We could say that Kant is an anti-realist with respect to the objective world while being an agnostic about the metaphysical claim regarding an existing object "outside" of spatiotemporal determinations. Kant is an anti-realist because he thinks that external 
and internal objects are not independent of the way we cognize them; both are subjected to our forms of intuition and the pure concepts of the understanding. However, external objects are not reducible to mere internal presentations, and that is something that is empirically proved in the same way that we distinguish between the appearance of a rainbow and the appearances of the rain and the sun. There is a causal distinction between illusions and reality, for even when the rainbow is a subjective appearance it is not an illusion, since the external cause of its appearance can be clearly established. On the other hand, Kant thinks that there may be reasons to believe that there are objects independent of the categories of understanding, but we cannot assert anything about them without making an illegitimate use of our cognitive faculties.

According to the conclusions of this essay, empirical realism is a weak position in front of the attacks of the argument from illusion, for the only tool this type of realist has against it is to try to offer a perceptual distinction, which as was explained, fails. Kant's transcendental idealism does not help either insofar as it cannot give the ontological ground needed to support the reality of the external world unless its transcendental move is interpreted at face value, i.e., taking objects as objects and not as representations. This move makes it possible to ground the externality of an object in the experience of spatiality perceived through our very body. Without its permanent receptivity, no experience of reality or illusion would emerge in our mind.

As for the type of realism found in the Yogasutra of Patañjali, scholars have interpreted it as defending a dualist metaphysical realism, since both a conscious principle and an unconscious objective principle are asserted. However, this characterization can be somewhat misleading because, while it is true that the Yogasütra makes such a metaphysical differentiation, it could be argued that they are not totally independent of each other. The soteriological aim of such a thorough analysis of our cognitive faculties is certainly the distinction and realization of the conscious principle as being independent of and free from the ever fluctuating unconscious matter. But this is in itself an epistemological process. The cognitive faculties are made the object of a phenomenological regress in which the mental activity is brought to arrest, a point in which the object-empty mind makes consciousness - which is here considered the principle of awareness - realize its own subjectivity. In a sense, the metaphysical distinction between consciousness and the object of consciousness is dependent upon the epistemological realization by consciousness itself in the form of a cognition like "This is not me". In fact, the whole purpose of the unconscious principle's existence is for that realization to happen. So in this sense, the whole manifestation of the objective world (including the mind) is dependent on the "miscognition" of the conscious principle (YS III.35 and IV.32).

This however, and interestingly enough, does not make of the yoga philosophy of Patañjali an idealism nor a complete anti-realism. Even though the whole manifestation of the world is dependent on that original cognitive-mutation, the truth value of "This is not me"- the cognition that liberates consciousness from the objective world - does not depend on whether the consciousness principle knows it or not (epistemological realism); for "the seer" is really not "the seen" (metaphysical 
realism). Wouldn't this again allow the introduction of the skeptical doubt? This objective world could be just the product of a miscognition. However, for Patañjali consciousness could not "miscognize" itself if there were nothing to be "miscognized" with. Thus, an incorrect or illusory cognition presupposes not only the possibility to be recognized as such, but also the objects upon which the illusion or the incorrect cognition is done.

Does this mean that the world, as known by the subject, is not totally independent to the way this cognizes it? It seems that Patañjali and Vyāsa would admit a degree of involvement of the cognitive functions in constructing the object of perception. The epistemology of the process of cognition in the Yogasütra is something that deserves an essay on its own, and thus we cannot expand on that here. However, it can be said that the interaction between the cognitive process and the physical world is understood in a realist way, in the sense that there is a causal relation between the internal and the external that would not happen if the effect were not already existent in the cause. This means that even if there is a conceptual element in the cognition of an object, it would not be able to occur hadn't there been an external physical configuration that provided the material for it and its application. In agreement with Kant, Patañjali sees the distinction between what is real and what is mere appearance as something that can be empirically and rationally detected. At the same time, such distinction cannot be only grounded on perceptual grounds if it does not want to be pray of the illusionist attack.

\section{ACKNOWLEDGEMENTS}

I want to thank Arindam Chakrabarti for his encouragement to write this paper and to the referees of this journal for their very pertinent corrections to an earlier draft.

\section{REFERENCES}

Balslev, Anindita N. (1983), A Study of Time in Indian Philosophy (Wiesbaden: Otto Harrassowitz).

Berkeley, George (1979), Three Dialogues between Hylas and Philonous (Indianapolis: Hackett Publishing Company).

Braj M., Sinha (1983), Time and Temporality in Samkhya-Yoga and Abhidharma Buddhism (New Delhi: Munshiram Manoharlal Publisher).

Burley, Mikel (2007), Classical Sämkhya and Yoga. An Indian Metaphysics of experience (New York: Routledge).

Cassam, Quassim (1993), "Inner Sense, Body Sense, and Kant's 'Refutation of Idealism' ", European Journal of Philosophy 1.2: 111-27.

Chakrabarti, Arindam (1992), "Idealist Refutations of Idealism", Idealistic Studies 22.2: 93-106. 
Crane, Tim and Farkas, Katalin (eds) (2004), Metaphysics. A Guide and Anthology (New York: Oxford University Press).

Descartes, René (1996), Meditations on First Philosophy, trans. John Cottingham (Cambridge University Press).

Devitt, Michael (1999), "A Naturalistic Defense of Realism", in Steven D. Hales (ed.), Metaphysics: Contemporary Readings (Belmont, CA: Wadsworth Publishing Company), 90-103.

Dummett, Michael (1982), "Realism", in Synthese 52.1: 145-65.

Förster, Eckart (1985), “Kant's Refutation of Idealism”, in Phlosophy, Its History and Historiography, Vol.3 of the Royal Institute of Philosophy Conferences: 287-303.

Guyer, Paul (1987), Kant and the Claims of Knowledge (New York: Cambridge University Press).

Hanna, Robert (2000), “The Inner and the Outer: Kant's 'Refutation' Reconstructed”, Ratio 13: 146-74.

Holland, A.J. (eds) (1985), Philosophy, Its History and Historiography (D. Reidel Publishing Company).

Inwagen, Peter Van (2015), "Objectivity", in his Metaphysics (Boulder, CO: Westview Press), 107-22.

Jakubczak, Marzenna (2008), "The sense of ego-maker in classical Sāmkhya-Yoga", Cracow Indological Studies vol. X: 235-253.

Kant, Immanuel (2006), Anthropology from a Pragmatic Point of View, trans. Robert B. Louden (New York: Cambridge University Press).

Kant, Immanuel, Critique of Pure Reason, trans. by Werner S. Pluhar (1996) (Indianapolis: Hackett Publishing Company).

Kumar, Shiv (1984), "Sāmkhya-Yoga Concept of Time", Annals of the Bhandarkar Oriental Institute 64 (Poona): 129-135.

Loux, Michael J. (eds) (2002), Metaphysics. A Contemporary Introduction (New York: Routledge).

Mass, Phillip (2013), “A Concise Historiography of Classical Yoga Philosophy”, in Eli Franco (ed.), Periodization and Historiography of Indian Philosophy (Vienna: Sammlung de Nobili, Institut für Südasien-, Tibet-, und Buddhismuskunde der Universität Wien / Publications of the De Nobili Research Library, 37), 53-90.

Patañjali, H. Āraṇya Swāmi (1983), Yoga Philosophy of Patañjali (Albany: State University of New York Press).

Prasad, Hari Shankar (1984), "Time and Change in Sāmkhya-Yoga", Journal of Indian Philosophy 12.1: 35-49.

Putnam, Hilary (1981), Reason, Truth, and History (New York: Cambridge University Press).

Sen, Sanat Kumar (1967), "Time in Sāmkhya-Yoga", Vishwarati Journal of Philosophy 4.1: 406-26.

Sharma, Ramesh Kumar (1992), "Reality of the External World: Yoga vs. Buddhist Idealism", Philosophy, Grammar, and Indology: Essays in Honour of Professor Gustav Roth, edited by H. S. Prasad (Delhi: Sri Satguru Publications), 221-31. 
Siderits, Mark (2007), Buddhism as Philosophy (Indianapolis: Hackett Publishing Company).

Sinha, Braj M. (1983), Time and Temporality in Samkhya-Yoga and Abhidharma Buddhism (New Delhi: India Munshiram Manoharlal Publishers).

Vogel, Jonathan (1993), "The Problem of Self-Knowledge in Kant's 'Refutation of Idealism': Two Recent Views", Philosophy and Phenomenological Research, 53.4: 875-87. 